\title{
The Effect of Official Development Assistance on Domestic Savings and Economic Growth in Egypt
}

\author{
Rasha M. Elakkad ${ }^{1} \&$ Asmaa M. Hussein ${ }^{1}$ \\ ${ }^{1}$ Faculty of Commerce and Business Administration, Helwan University, Egypt \\ Correspondence: Rasha M. Elakkad, Lecturer of Economics at the Faculty of Commerce and Business \\ Administration, Helwan University, Egypt.
}

Received: September 30, 2021

Accepted: October 24, $2021 \quad$ Online Published: October 28, 2021

doi:10.5539/ijef.v13n12p33

URL: https://doi.org/10.5539/ijef.v13n12p33

\begin{abstract}
The Egyptian economy has passed through several overlapping phases of economic development over the last decades, starting in 1950s. However, the launch of the Open Door Policy in 1974 allowed a greater role for official development aid funds to finance economic growth. In economics literature, the role of foreign aid in financing economic growth and complementing domestic savings has been controversial. This paper firstly, outlines in general main types and channels of foreign aid; secondly, gives a historical overview of foreign aid and thirdly; investigates the impact of official development assistance on domestic savings and thus on economic growth in Egypt over the period of 1965 to 2020 according to data available from the World Bank. The empirical analysis is conducted through a two-equation model through which the researchers have concluded contradictory results where foreign aid positively affects gross domestic savings and negatively affects economic growth.
\end{abstract}

Keywords: official development assistance, economic growth, Gross Domestic Savings, Egypt

\section{Introduction}

Foreign aid is roughly voluntary flow of capital from developed donor country to less developed recipient country. Aid can be either a loan or a grant. Aid also can be bilateral: from one country to another -this constituted around $70 \%$ of total aids in 2020; or multilateral: from donor countries to international organizations. These organizations then distribute aid funds among the developing countries; its proportion is the remaining $30 \%$.

Foreign aid also can come from official government sources (80-85\% of developmental aid) as official development assistance (ODA) or from private organizations such as "non-governmental organizations" (NGOs), foundations and other development charities (the remaining 15-20\%) (Thapa, 2020).

There are several successful stories of poverty reduction and economic development in Southeast Asian and Latin American countries. These economic successes prove that aid monies can enhance the economies of developing countries that deserve receiving aid funds. On the other hand, by comparing similar developing economies it was found that many African countries are still struggling to achieve economic and industrial development despite receiving foreign aid.

Because of these mixed results, there has been a growing debate on the role and effectiveness of foreign aid in financing economic development and complementing domestic savings in the aid- recipient countries and in global development cooperation (Kaiser, 2020).

The Egyptian economy has passed through several overlapping phases of economic development over the last decades, starting in 1950s when Egypt received her first economic ODA from the USA in 1948. However, the launch of the Open Door Policy in 1974 allowed a greater role for the ODA as an external source of financing economic growth. The military assistance started after signing the Egyptian-Israeli peace agreement in 1978, where the USA announced annual economic and military aid to Egypt.

The Egyptian government has been receiving ODA from both several multilateral and bilateral sources. However, these flows, as proved by time-series data and by donor countries' foreign policies, are fluctuating and are decreasing over time.

The study proceeds as follows; analyzing the concept of ODA (definition and channels of flow to developing 
countries); presenting a brief historical overview of foreign aid; analyzing ODA flowing to Egypt and finally investigating the significance of ODA on gross savings and thus its impact on economic growth in Egypt over the period of 1965 to 2020 .

\section{Definition and Channels of Foreign Aid}

There is no one agreed upon definition of foreign aid; however the Development Assistance Committee (DAC) of the Organization for Economic Cooperation and Development (OECD) presented a definition that seemed the most reliable as it defined foreign aid as transfers made from developed to less-developed countries for the purpose of improving human conditions. Also, the DAC defined ODA as aid funds received by developing countries' governments in order to enhance economic development and welfare. ODA can take two basic forms. The first is Grants, which are provided to countries with neither interest nor provision for repayment. The second is Soft loans, which have to be repaid with an interest rate lower than that imposed on loans from commercial banks.

In an attempt to closely determine the expenditures included in the ODA; the DAC considered the following inflows; Technical and financial cooperation; Funding development organizations; Debt relief; Donor countries spending on citizens from developing countries (e.g. students and refugees); Developing country-specific direct research (for instance combating domestic diseases) and Aid flows from non-governmental organizations, private foundations and research institutes (Schirl \& Sieler, 2012).

Three basic channels through which these ODA monies can flow from a developed country to developing and less developed countries: bilateral, multilateral and private channels. The first two are official, while the latter is clearly an unofficial channel.

Since the creation of the OECD/DAC in 1960, the main donor countries to benefit their own interests established specific agencies that take the responsibility of; setting aid policies according to their internal laws; negotiating aid-payment arrangements and implementing and managing aid projects. Thus, in bilateral aid, the developed country plays a dual role of being the provider and also the implementer of aid program with the ultimate target of serving its foreign policy goals. That's why bilateral aids in some cases fail to meet the development requirements of the developing countries (Zhou, 2001).

Multilateral aid is provided through major aid agencies such as the International Development Association (IDA) that belongs to the World Bank through providing zero to low-interest loans and grants to fund development programs that reduce inequalities and improve living conditions and thus reduce poverty in the recipient countries. Besides, there are also regional development banks based mostly upon the World Bank model, including the Asian Development Bank, the African Development Bank and the Inter-American Development Bank.

Other agencies that belong to the United Nations are specialized in funding more specific developmental projects. Key among which are the World Food Program (WFP), the United Nations Development Program (UNDP), the United Nations Children's Fund (UNICEF), the World Health Organization (WHO), the Food and Agriculture Organization (FAO) and the United Nations Educational, Scientific and Cultural Organization (UNESCO).

These multilateral aid agencies don't only provide funds, however they additionally serve other functions that include: providing economic analysis and recommendations, publishing research reports, assembling aid statistics, deciding areas in need for funding then evaluating their performance, and finally coordinating between donor countries. Unlike Bilateral aid, multilateral aid agencies set and manage their own aid programs independently of donor countries.

Besides these official channels, ODA can also flow through unofficial channels. For instance, the United States Agency for International Development (USAID) is playing a vital role in providing aids worldwide since 1961. USAID is an independent agency of the US federal government that's primarily responsible for implementing civilian aid projects and providing development assistance.

\section{Historical Trend of Foreign Aid}

It's worth mentioning that academic research has helped in shaping international aid policies. During the 1950s and early 1960s, foreign aid was led by governments of recipient developing countries that had newly achieved independence and were widely trusted to use aid funds to solve their development problems. As a result, donor countries and aid agencies injected aid funds in large capital-intensive projects in the developing countries in a manner influenced by the Harrod-Domar and W. Arthur Lewis' growth models neglecting policies related to labor, human capital, and productivity. 
However, during the late 1960s and 1970s, aid policies have been altered with the several changes that affected the international environment. For instance, the weak performance of the dominant agricultural sector in most recipient African countries; the increased bureaucratic corruption and economic development levels lower than that expected altogether with the ascendance of Solow's neoclassical growth model; and the development of the 'basic needs' approach to welfare economics.

Consequently by the late 1970s, donor countries began to decrease their financial aid and to establish management mechanisms for these funds putting forward various kinds of conditionality for directly influencing not only the economic but also the political systems of recipient governments in an attempt to achieve real long-term development.

During the 1980s and beginnings of the 1990s, aid policies were greatly influenced with the academic research related to the positive effects of both trade openness and exports' expansion on economic growth. For this reason, ODA switched to be conditioned on the success of the recipient governments' open door policies and the reduction of foreign trade restrictions.

Later, during the 1990s, donor countries followed the 'program ownership' approach as they became more flexible, and begun to incorporate recipient governments in the design and management of aid programs. This was one main way to improve the relationship between both donor and recipient countries. With more capital mobility and the international transmission of currency crises, aid policies and aid agencies advocated limited use of capital controls to avoid financial destabilization.

In the beginning of the 2000s, Non-Government Organizations (NGOs) were encouraged to facilitate aid activities through acting as a mediator between the donor governments/agencies and recipient countries. Accordingly, aid funds move from NGOs windows/facilities located in donor countries to local NGOs. Three main reasons behind this; firstly, aid agencies argue that corruption and poor management of the recipient governments lead to aid waste. If more beneficiaries are involved then the whole society can develop.

Secondly, aid donors sometimes use these funds to alter the development process in recipient countries according to their foreign policy. Thirdly, these NGOs with their long-term experience inside the developing countries and their technical skills are capable of responding wisely to local development needs and thus can supplement the gaps in ODA (Zhou et al., 2015).

It's also worth-mentioning that the set of the Millennium Development Goals (MDGs) in 2000 and the subsequent more recent Sustainable Development Goals (SDGs) in 2015 have greatly influenced global aid policies. These list of goals explicitly committed industrialized/developed countries to raise their ODA to the developing/underdeveloped countries in an attempt to achieve the ultimate goals of reducing global poverty and achieving the SDGs by the year 2030 .

\section{Official Development Assistance to Egypt}

The Egyptian government has received tens of billions of dollars of official foreign aid from both multilateral [e.g. the International Monetary Fund (IMF) and the World Bank (WB)] and bilateral sources (e.g. the Gulf Cooperation Council). All these Net ODA is currently below the levels of Egypt's peer countries. Further, the bilateral ODA decreased by more than $3 \%$ to the underdeveloped countries and by more than $4 \%$ to African countries in general since 2017. This, consequently, implies that net ODA will continue to decrease to Egypt from the low level of $1.2 \%$ of GNI to $0.6 \%$ by 2030, as expected. Such reduction in ODA forms a challenge for Egypt to attract other forms of external financing (The Organization for Economic Co-operation and Development [OECD], 2012).

For instance, USAID provided the Egyptian government around \$28.6 billion over the period 1975-2009. However, between 2007 and 2009, net ODA flowing to Egypt decreased from almost \$1.7 billion to 1billion in 2009. This huge decline is attributed to the cutbacks in both the US aid provisions and the global ODA in the aftermath of the global financial and Euro zone crises (Abou El Nour, 2014).

Consequently, the composition of net ODA flowing to Egypt slightly changed where the bilateral sources constituted 79\% instead of 73\% of total development assistance in 2009. The Arab Fund for Economic and Social Development (AFESD) and the European Union (EU) became the main contributors of this bilateral assistance.

In the wake of 2011 revolution, most international donors have injected more aid funds in Egypt. For instance, the Egyptian government has received $€ 449.29$ (\$600) million from the EU over the period 2010-2013, with conditioning priorities for supporting democratic reform, improving the economic competitiveness and realizing development goals of the Egyptian economy (OECD, 2012). 
Top bilateral donor countries among the EU member states were; Germany, France, and the UK granting Egypt with \$464, \$171.8, million respectively in 2018-2019. Other main bilateral donors include; Japan granting \$326.2 million and Korea granting \$70.9 million. The AFESD also granted Egypt with gross ODA of \$186.9 million in 2018-2019. Kuwait, Saudi Arabia and the United Arab Emirates are top Arab bilateral donor countries providing Egypt with \$473.8, \$395.7, and \$150.6 million respectively in the same year (Elagati, 2013).

Concerning the International organizations; the IMF, the WB and the UN provide assistance to the Egyptian government to help stimulate the economy and alleviate poverty. The UN, for instance, began providing ODA to Egypt since 1953 and the UNDP has been working with the Egyptian government on achieving efficient management and usage of water and energy sources as well as facilitating credit provision for small to medium-sized enterprises to create more jobs in Egypt.

Actually, the nature of the UNDP's assistance to Egypt has become even more focused over the past 20 years. Specifically, in 2017, the UNDP presented its Country Program Document (CPD) that guides Egypt's road through a five-year plan over the period 2018-2023 focusing on inclusive growth, green economy and gender equality. This typically coincides with the SDG set in 2015 by 195 -member states of the UN, including Egypt, committed to meet targets in order to realize a better world by 2030 as mentioned earlier.

\section{Literature Review}

Savings and investments have been at the heart of economic literature as means for achieving economic development since the beginning of the discipline. Across countries and over time; increasing GDP growth rates are associated with higher investments and savings rates and vice versa. Therefore, directing savings to the various investment fields is one of the main requirements for achieving increasing rates of economic development (Morsi \& Moscardini, 2001).

A savings investments (S-I) gap; can be compensated for by foreign saving or foreign borrowing. These foreign capital inflows (FCI) flowing to any country and Egypt is not an exception, can take many forms such as; returns from exports, foreign aid and grants and direct and indirect foreign investment (Thirlwall, 2004).

Despite that logic behind the crucial role played by foreign aid for financing economic development, the debate over the effectiveness of these funds has never been resolved. Empirical studies examining the relation between foreign capital inflow and economic development show evidence for and against the theoretical arguments concerning the impact of aid funds (Alhagrasy \& Alhakimi, 2015).

The supporters of foreign aid argue that; aid funds permit developing and under-developed countries to enhance both social and economic conditions through supplementing their insufficient domestic savings. Besides, aid funds can fill the foreign exchange gap and hence allow the developing countries to purchase the needed capital goods imports. Without such aids, these countries will not achieve the desired levels of economic development.

Papanek (1973) for instance, applied a cross-sectional regression analysis on 34 and later on 51 countries during the 1950s and the 1960s respectively. According to his study; all forms of foreign flows (including foreign aid and foreign investment) and domestic savings are explanatory variables. Eventually, he concluded a positive effect of foreign aid on economic growth where aid funds, unlike domestic savings, can fill both the foreign exchange gap and the savings gap (Papanek, 1973).

Dhakal and Upadhyay (1996), in their study on eight developing Asian and African countries, conducted a causality test on the relation between foreign aid and economic growth. They found that except for Kenya and Nepal, foreign aid is positively and significantly related to economic growth (Dhakal et al., 1996).

Fayissa and El-Kaissy (1999), applied a cross-sectional analysis on 80 LDC over the period; 1971-1990. Their study concluded also that foreign aid positively affects economic growth in these developing countries given that they supplement and don't replace domestic savings, which coincides with the economic theory (Fayissa \& El-Kaissy, 1999).

On the other hand, studies that found adverse impact of ODA on economic growth argue that aid recipient governments misuse these funds through spending them directly on financing their expenditures instead of imposing taxes. Consequently, this leads to lower savings and lower economic growth. Thereby, domestic savings tend to decrease with high foreign capital inflow. In addition, foreign aid may cause the Dutch disease, which leads to currency appreciation and thus higher inflation rates. Both will reduce exports and raise more need for aid funds to finance increasing imports. This is commonly known in economic literature as aid dependency. However, opponent studies argue that this negative relation is the outcome of several factors in the recipient countries such as; economic policies, state intervention, business cycles, and stability of foreign aid flow (Joseph, 2014). 
For instance, Griffin and Enos (1970) tested this hypothesis on 32 developing countries. The authors concluded an insignificant effect of foreign economic assistance on economic growth. Further, these monies could hinder economic development by lowering the domestic savings rates.

Bowels (1987) applied a Granger causality test on the relationship between foreign aids, gross savings and economic growth, using both; time series and cross-sectional data for 20 developing countries over the period 1960-1981. The test results were ambiguous where the author found different nature and direction of causality across the tested countries. In addition, half of his sample size showed no causal relation between savings and foreign aid.

Also, Djankov et al. (2006) found that foreign aid negatively affects economic growth and positively affects government expenditure. According to the authors, this positive relation is explained by the fact that aid funds are easy resources spent on non-productive activities that don't not induce investment. This consequently asserts that the effectiveness of these funds on realizing economic growth depends on how they are allocated among different sectors of the economy.

During the same year, 2006, Burke and Ahmadi-Esfahani conducted a study on three South East Asian countries over the period 1970-2000. They tested the impact of foreign aid on economic growth through simultaneous equations where both growth and savings are estimated. They concluded an insignificant effect of foreign aid on economic growth. Further, these funds did not displace or even complement domestic savings in these countries (Burke, \& Ahmadi-Esfahani, 2006).

Later, Basnet (2013) also investigated the impact of foreign aid on domestic savings and economic growth in five South Asian countries. He concluded contradictory results where aid funds have a positive effect on economic growth that is counterbalanced by their adverse effect on domestic savings in the sampling countries.

Likewise, in 2016 Sabra and Eltalla concluded -through their studies on Arab countries, that increasing aid inflows accelerate imports rather than exports, which hinder investment and don't help the economy to achieve the desired and expected rates of economic growth.

\section{Empirical Investigation}

Many developing and less developed countries from all over the world depend on the simple Harrod-Domar growth model in setting their development plans. According to this model; higher saving rates affect positively on economic growth (Thirlwall, 2004).

The dual-gap model is considered as an extension of the Harrod-Domar Growth model. This model assumes the existence of two gaps- a" saving" gap and a" trade "gap. Insufficient domestic saving (Savings-Investment gap), can be compensated for by foreign capital inflows. This can be shown through the following national accounts:

$$
\begin{aligned}
& Y=C+I+X-M \\
& I-S=M-X=F
\end{aligned}
$$

Where: $\mathrm{Y}=$ income, $\mathrm{C}=$ consumption, $\mathrm{I}=$ investment, $\mathrm{F}=$ foreign capital inflows, $\mathrm{X}=$ exports and $\mathrm{M}=$ imports.

Foreign capital inflows flowing to any country, can take several forms among which are foreign aid and grants. These foreign flows permit investment to exceed domestic saving by allowing imports to exceed exports.

In most developing countries the gross savings rates are lower than the required rates. Egypt is no exception, where according to the World Bank database in 2019 the gross domestic savings as percentage of GDP was 9.974; whereas the gross capital formation of the same year as percentage of GDP was 18.213

Gross savings aren't only limited, they are also largely fluctuating. For instance, in 1995, gross savings reached its maximum level of 35.746 as percentage of GDP since the 1970s to start deteriorating back to 17.584 in 2000 and to increase to 23.624 (as percentage of GDP) in 2008 before reaching its minimum level in 2015 to 9.59 (as percentage of GDP). This S-I gap together with these huge fluctuations in gross saving rates force Egypt to rely heavily on foreign aid funds to finance investment projects. (Mansoor et al., 2017).

The model in hand is based on two main equations of variables under consideration; economic growth and saving. The choice of two-equation model is made basically to avoid the simultaneity bias that usually occurs in other single-equation models (ordinary least-squares OLS) since some of the explanatory variables (for instance foreign aid and government spending) are more likely to be statistically correlated and thus might not be truly exogenous.

$$
\begin{gathered}
L n G D P P C=\beta_{0}+\beta_{1} \ln O D A I D+\beta_{2} \ln G D S+\beta_{3} L N G O V E X P+\varepsilon \\
L n G D S=\alpha_{0}+\alpha_{1} \ln O D A I D+\alpha_{2} \ln G D P P C+\alpha_{3} \ln G C F+v
\end{gathered}
$$


Where:

- GDPPC is GDP per capita in constant \$US 2010 prices.

- ODAID is net official development assistance and official aid received in constant \$US 2018 prices.

- GDS is the gross domestic saving in current \$US prices.

- GOVEXP is government final consumption expenditures in constant \$US 2010 prices.

- GCF is the gross capital formation in constant \$US 2010 prices.

- $\varepsilon$ and $\mathrm{v}$ are error terms.

- The parameters $\beta_{1}, \beta_{2}, \beta_{3}$ and represent the elasticities of GDPPC with respect to ODAID, GDS and GOVEXP.

- The parameters $\alpha_{1}, \alpha_{2}, \alpha_{3}$ and represent the elasticities of GDS with respect to ODAID, GDPPC and GCF.

The paper's main interest is to investigate the impact of ODA on economic growth in Egypt. This is generally achieved when foreign aids supplement domestic savings in order to increase gross investments and thus allow the economy to achieve economic growth. For that reason, the dependent variables in the two equations are; GDPPC which represents GDP at constant 2010 \$US prices divided by population, this is the most preferable proxy of economic growth as it takes population into consideration, and the gross domestic saving (GDS).

The other variables of the model include; GOVEXP as a proxy for fiscal discipline. It includes current government expenditures on; goods, services, national defense and security. The rationale behind adding GOVEXP as an explanatory variable in the model is to reflect the controversy over the government's ability to balance its expenditures with received revenues and to spend these funds in developmental purposes. (Barro, 1990) Likewise, Gross capital formation (GCF) is an excellent proxy of domestic investment which is added among the explanatory variables because of its effect on economic growth.

It's worth-mentioning that Trade Openness which is defined as the sum of exports and imports as a percentage of GDP, has been added and later removed from the model. It is generally believed In Economic Literature that trade openness plays a vital role in achieving economic growth through allowing better exploitation of resources and achievement of economies of scale. For that reason it seemed appropriate to add it as an explanatory policy variable. However adding trade openness as an independent variable in both equations over the study period proved to be statistically insignificant on both GDP per capita and gross domestic savings.

This paper analyzes a time series data of Egypt over the period 1965 to 2020 according to the availability of data from the World Development Indicators of the World Bank database. Variables of the model are all treated in natural logarithm form to give logarithm values for negative numbers and reduce multicollinearity. All coefficients are being standardized. The results of the two stage least squares estimation of equation (1) are summarized in Tables 1,2 and 3. The findings prove that the independent variables; ODAID, GDS and GOVEXP collectively explain 98.9\% of changes in GDP per capita of Egypt over the period 1965-2020 and all are statistically significant and positively related to the dependent variable GDP per capita except for foreign aid which is found to be negatively related.

Table 1. Model summary

\begin{tabular}{cccccc}
\hline Model & $R$ & $R$ Square & Adjusted $R$ Square & Std. Error of the Estimate & Model \\
\hline 1 & $.995^{\text {a }}$ & .989 & .988 & .05069 & 1 \\
\hline
\end{tabular}

Predictors: (Constant), GOVEXP, ODAID, GDS.

Table 2. ANOVA ${ }^{\mathrm{b}}$

\begin{tabular}{|c|c|c|c|c|c|c|}
\hline \multicolumn{2}{|c|}{ Model } & \multirow{2}{*}{$\begin{array}{c}\text { Sum of Squares } \\
12.312\end{array}$} & \multirow{2}{*}{$\frac{D f}{3}$} & \multirow{2}{*}{$\begin{array}{c}\text { Mean Square } \\
4.104 \\
\end{array}$} & \multirow{2}{*}{$\begin{array}{c}F \\
1.597 \mathrm{E} 3\end{array}$} & \multirow{2}{*}{$\begin{array}{l}\text { Sig. } \\
.000^{\mathrm{a}}\end{array}$} \\
\hline 1 & Regression & & & & & \\
\hline & Residual & .134 & 52 & .003 & & \\
\hline & Total & 12.446 & 55 & & & \\
\hline
\end{tabular}

a. Predictors: (Constant), GOVEXP, ODAID, GDS

b. Dependent Variable: GDPPC 
Table 3. Coefficients ${ }^{\mathrm{a}}$

\begin{tabular}{|c|c|c|c|c|c|}
\hline \multirow[b]{2}{*}{ Model } & \multicolumn{2}{|c|}{ Unstandardized Coefficients } & \multirow{2}{*}{$\frac{\text { Standardized Coefficients }}{\text { Beta }}$} & \multirow[b]{2}{*}{$T$} & \multirow[b]{2}{*}{ Sig. } \\
\hline & $B$ & Std. Error & & & \\
\hline (Constant) & -4.907 & .359 & & -13.663 & .000 \\
\hline ODAID & -.036 & .007 & -.079 & -5.223 & .000 \\
\hline GDS & .148 & .014 & .392 & 10.350 & .000 \\
\hline GovExp & .417 & .025 & .629 & 16.861 & .000 \\
\hline
\end{tabular}

a. Dependent Variable: GDP.

The results of equation (2) are shown in Tables 4, 5 and 6, where the variables; ODAID, GCF and GDPPC explain $93.7 \%$ of the variations in the dependent variable. All variables are statistically significant and positively related to gross domestic savings in Egypt over the study period except for GCF which is insignificant.

Table 4. Model summary

\begin{tabular}{ccccc}
\hline Model & $R$ & $R$ Square & Adjusted R Square & Std. Error of the Estimate \\
\hline 1 & $.968^{\mathrm{a}}$ & .937 & .933 & .32556 \\
\hline
\end{tabular}

a. Predictors: (Constant), GDPPC, ODAID, GCF.

Table 5. ANOVA ${ }^{\mathrm{b}}$

\begin{tabular}{cccccc}
\hline & Model & Sum of Squares & Df & Mean Square & Sig. \\
\hline 1 & Regression & 81.771 & 3 & 27.257 & 257.173 \\
& Residual & 5.511 & 52 & $.000^{\mathrm{a}}$ & \\
& Total & 87.283 & 55 & & \\
\hline
\end{tabular}

a. Predictors: (Constant), GDPPC, ODAID, GCF.

b. Dependent Variable: GDS.

Table 6. Coefficients ${ }^{\mathrm{a}}$

\begin{tabular}{|c|c|c|c|c|c|c|}
\hline \multirow[b]{2}{*}{ Model } & & \multicolumn{2}{|c|}{ Unstandardized Coefficients } & \multirow{2}{*}{$\begin{array}{c}\text { Standardized Coefficients } \\
\text { Beta }\end{array}$} & \multirow[b]{2}{*}{$T$} & \multirow[b]{2}{*}{ Sig. } \\
\hline & & $B$ & Std. Error & & & \\
\hline \multirow[t]{4}{*}{1} & (Constant) & -2.342 & 1.771 & & -1.322 & .192 \\
\hline & GDPPC & 1.630 & .500 & .616 & 3.262 & .002 \\
\hline & ODAID & .170 & .042 & .143 & 4.040 & .000 \\
\hline & GCF & .395 & .221 & .339 & 1.791 & .079 \\
\hline
\end{tabular}

a. Dependent Variable: GDS.

\section{Conclusion}

The paper investigates the effect of official development assistance on both domestic savings and economic growth in Egypt over the period of 1965 to 2020. The model used by the researchers is composed from two equations. The first has GDP per capita (as a proxy for economic growth) as the dependent variable whereas net official development assistance and official aid received, gross domestic saving and government final consumption expenditures are the independent variables. All variables are statistically significant and positively related to GDP per capita which coincides with the economic theory, except for foreign aid which is found to be significant but negatively related. This implies that the increase in official aid can hinder economic growth in Egypt. Theoretically, and for Egypt as well, this can be attributed to the Dutch disease, where foreign aid funds received by the economy leads to currency appreciation and higher inflation rate. Consequently, exports will decrease and imports will increase. Both affects negatively on economic growth.

Concerning the second equation, both GDP per capita and net official development assistance and official aid received are significant and positively related to gross domestic saving. This actually coincides with the economic theory, where these funds flowing into the economy can complement domestic savings and boost investment. The model however, found negative relation between gross capital formation (as a proxy for investment) and domestic savings. 
Hence, the paper has concluded a contradictory result, where the positive effect of foreign aid on gross domestic savings is counterbalanced by its negative effect on economic growth in Egypt. Therefore, the fluctuations and instability of these funds flowing to Egypt, with their anticipated drop by 2030 obliges the government to search for and rely on other sources of foreign capital that can actually enhance economic growth. The paper also opens the door for further investigation about the relation between trade openness and economic growth.

\section{References}

Alhagrasy, A. A., \& Alhakimi, S. S. (2015). The impact of foreign aid and FDI on economic growth: The case of Egypt. Benha University, Egypt.

Basnet, H. C. (November 2013). Foreign aid, Domestic savings and economic growth in South Asia. International Business \& Economics Research Journal (IBER), 12(11), 1389-1394. https://doi.org/10.19030/iber.v12i11.8176

Bowels, P. (1987). Foreign aid and domestic saving in less developed countries: Some tests for causality. World Development Journal, 15, 789-796. https://doi.org/10.1016/0305-750X(87)90060-X

Burke, P. J., \& Ahmadi-Esfahani, F. Z. (April 2006). Aid and growth: A study of South East Asia. Journal of Asian Economics, 17(2), 350-362. https://doi.org/10.1016/j.asieco.2006.02.006

Dhakal, D., Upadhyaya, K. P., \& Upadhyay, M. P. (1996). Foreign aid, Economic growth, and causality. International Review of Economics and Business, 43(3).

Djankov, S., Garcia-Montalvo, J., \& Reynal-Querol, M. (2006). Does foreign aid help? Cato Journal, 26(1). https://doi.org/10.2139/ssrn.896550

Elagati, M. (2013). Foreign funding in Egypt after the revolution. AFA, Fride and Hivos.

Fayissa, B., \& El-Kaissy, M. I. (September 1999). Foreign aid and the economic growth of developing countries (LDCs): Further evidence. Studies in Comparative International Development, 34, 37-50. https://doi.org/10.1007/BF02687626

Griffin, K. B., \& Enos, J. L. (1970). Foreign capital, Domestic savings and economic development. Oxford $\begin{array}{lllll}\text { Bulletin of } \text { Economics } & \text { Statistics, } & 32(2), & 99-112 .\end{array}$ https://doi.org/10.1111/j.1468-0084.1970.mp32002002.x

Joseph, V. M. (November 2014). Impact of official development assistance on economic growth in Kenya (X50/60182/2013). A Research paper submitted to the School of Economics in partial fulfillment of the requirements for the award of the degree of Master of Arts in Economics of the University of Nairobi.

Kaiser, M. S. (2020). Aid recipients, global development cooperation and the sustainable development goals. In F. W. Leal, A. M. Azul, L. Brandli, S. A. Lange, P. G. Özuyar, \& T. Wall (Eds.), No Poverty. Encyclopedia of the UN sustainable development goals. Springer, Cham. https://doi.org/10.1007/978-3-319-69625-6_84-1

Khaled, A. El N. (2014). An analytical study of the Egyptian system of aid coordination and management. The International Journal of Applied Economics and Finance, 8(1), 1-16. https://doi.org/10.3923/ijaef.2014.1.16

Mansoor, S., Baig, M. A., \& Javid, M. (July 2017). Foreign aid volatility and economic growth: A case study of Pakistan. International Journal of Economics, Finance and Business Management Studies, 4(1).

Morsi, C. M., \& Moscardini, A. (2001). Savings - Investments model in Egypt. School of Computing, Engineering and Technology, University of Sunderland, UK.

OECD. (2012). Aid effectiveness: Progress in implementing the Paris declaration. Better aid (Vol. II, Country Chapters). OECD Publishing, Paris. https://doi.org/10.1787/9789264125780-en

Papanek, G. F. (1973). Aid, Foreign private investment, Savings, and growth in less developed countries. Journal of Political Economy, 81(1), 120-130. https://doi.org/10.1086/260009

Sabra, M. M., \& Eltalla, A. (April, 2016). Foreign aid, Domestic savings and economic growth in selected MENA countries. Business and Economic Research, 6(1), 352-362. https://doi.org/10.5296/ber.v6i1.9204

Schirl, N., \& Sieler, S. (29 October 2012). Official development assistance (ODA) -Is the concept still in step with the times? KFW- Development Research, (7).

Thapa, I. (July 2020). Foreign aid: Positive and negative impact in developing countries. Public administration campus, Tribhuvan University, Nepal. https://doi.org/10.13140/RG.2.2.19155.81448 
Thirlwall, A. P. (2004). The mobilization of savings for growth and development in developing countries. University of Kent, U.K.

Zhou, H. (2001). The United States: Foreign aid as a strategic tool. In H. Zhou (Ed.), Foreign Aid and International Relations. China Social Sciences Press.

Zhou, H., Zhang, J., \& Zhang, M. (2015). Foreign assistance: Substance and practice. chapter two from the book: Foreign Aid in China. Social Sciences Academic Press (China) and Springer-Verlag Berlin Heidelberg. https://doi.org/10.1007/978-3-662-44273-9_2

\section{Copyrights}

Copyright for this article is retained by the author(s), with first publication rights granted to the journal.

This is an open-access article distributed under the terms and conditions of the Creative Commons Attribution license (http://creativecommons.org/licenses/by/4.0/). 